\title{
Biochemical and technological view of broiler chicken meat with pectoral
}

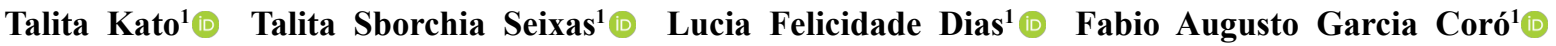 \\ Mayka Reghiany Pedrão ${ }^{1^{*}}$ (1)
}

${ }^{1}$ Programa de Pós-graduação em Tecnologia de Alimentos (PPGTAL), Universidade Tecnológica Federal do Paraná (UTFPR), 86036-370, Londrina. PR, Brasil. E-mail: maykapedrao@utfpr.edu.br. "Corresponding author.

\begin{abstract}
There has been a significant advance in the poultry industry, and new technological and biological processes have accompanied the development of animals and inputs. Alongside the new possibilities for growth, there has been an emergence of new paradigms, including the rise of myopathies among which PSE, DFD, deep pectoral myopathy, oregon disease, acid breast, white stripping, wooden breast and spaghetti meat stand out. They cause considerable damage to the industry, as well as to ride hypotheses for studies in an attempt to better describe them. Researches seek to know about the behavior of proteins and specific protein groups in these anomalies. Groups of proteases are determinant to understand what may be occurring in muscle activity and; consequently, to understand the process in a more detailed way. Therefore, proteolytic systems may be acting on abnormal tissues. Proteases act differently in birds and mammals, but how altered they may be is still unknown. Besides, it is essential to relate the activities of these proteases, measures that indicate technological aspects that are relevant to meat quality standards. These quality standards must be directly associated with the consumption of raw meat in the material destined for processing, regardless of the final product. The important thing is to guarantee information that will lead the industry and consumers that will have, even with the anomaly developed, products that are nutritionally safe. This review discusses the biochemical and technological changes in poultry with pectoral anomalies, and how this affectsmeat quality.
\end{abstract}

Key words: white striping, wooden breast, proteases, oxidation, meat quality.

Visão bioquímica e tecnológica de carne de frango com anomalias peitorais

RESUMO: Sabe-se que houve um avanço considerável na indústria de frangos de corte nos últimos sessenta anos, e que consequentemente novos processos tecnológicos e biológicos acompanharam o desenvolvimento tanto de animais quanto de insumos. Com novas possibilidades de crescimento houve também o surgimento de novos paradigmas, sendo um deles o surgimento de diferentes tipos de miopatias. Como o peito é um dos pontos fortes da indústria de aves, muito tem se estudado sobre o assunto, e pode-se destacar PSE, DFD, Miopatia peitoral profunda ou peito verde, Peito ácido, White striping, Wooden breast e Spaghetti meat são as mais comuns. As três ultimas são mais recentes quando comparadas as outras citadas, e ainda há necessidade de compreensão do seu desenvolvimento, mas sabe-se que acarretam prejuizos consideráveis para o setor, além de permear a mente dos pesquisadores com hipóteses para estudos na tentativa de descrever melhor o que ocorre, o porquê de sua ocorrência e, futuramente, compreende-la ao ponto de poder gerar mecanismos para minimiza-las ou até mesmo suprimi-las. Os grupos de pesquisa nos USA, Italia, Brasil, Finlândia, Canadá e Inglaterra estão em busca destas respostas, todavia, até o momento, a Itália é o país que mais tem reportado informações sobre a problemática em torno de White striping e Wooden breast. Mas com todos os artigos até o presente momento, pouco se sabe sobre o comportamento de proteinas e grupos proteicos especificos nestas anomalias. O que há descrito trata-se de diferença entre conteúdo proteico e colágeno e taxa de degradação proteica. Contudo, sabe-se que grupos de proteases são determinantes para compreender o que pode estar ocorrendo na atividade muscular e consequentemtne entender o processo de forma mais detalhada. Logo, uma possibilidade é a compreensão de sistemas preoteolícos como as calpaínas, caspases e como podem estar atuando nos tecidos anômalos. Sabe-se que estas proteases atuam de maneira diferenciada em aves, quando comparada a mamiferos, mas o quão alterada podem estar ainda não se sabe. Além disto, é importante relacionar a atividades destas proteases com medidas que indiquem aspectos tecnológicos que sejam relevantes para padrões de qualidade de carnes. Estes padrões de qualidade devem estar diretamente associados ao consumo da carne in natura quanto ao material destinado à processamento, não importando qual seja o produto final. O mais importante é garantir informações que levem a indústria e os consumidores que terão, mesmo com a anomalia desenvolvida, produtos seguros nos aspectos nutricionais, bioquímicos e tecnológicos. Com base nestas breves informações, foi definido o procedimento metodológico desta proposta que permeia aspectos que incluam o maior número de informações sobre a alteração White striping em carne de aves, e com a reunião destas informações a possibilidade de entender melhor o que ocorre nestas carnes, levando a um conjunto de analises ainda não relatado na atual literatura.

Palavras-chave: peito de frango estriado, peito de frango amadeirado, proteases, oxidação, qualidade de carnes. 


\section{INTRODUCTION}

According to the Brazilian Animal Protein Association (ABPA, 2018), 33\% of Brazil's chicken production in 2017 was exported. Among the most commercialized products, chicken cuts stand out, corresponding to $59 \%$, and one of the most economically important is chicken breast. In 2017, Brazil produced 13.05 million tons of chicken meat, performing $67 \%$ of which for the internal market with per capita consumption of $42.04 \mathrm{~kg}$. These data associate with OECD-FAO (2018), reported the chicken meat increase $17 \%$ between 2008 and 2017 and became the most popular source of animal protein in the world. According to Normative Instruction No. 20, dated July 21, 1999, the Ministry of Agriculture, Livestock and Food Supply (MAPA), chicken meat must have a uniform overall appearance without blood accumulation, without foreign bodies and dark spots, besides of having fine muscle fibers. The color should be uniform, unspotted, ranging from reddish yellow to whitish-yellow, with chicken breast having a lighter shade. There is a darkening of the surface by the action of microorganisms with aging. Finally, the consistency is usually firm, soft and slightly wet (BRASIL, 1999).

With this high market, the trend of the production of Brazilian chicken cuts is to increase. There is a concern with the quality of this product in parallel with the need to slaughter larger chickens, which correspond to higher yields in less time. When all these factors are reached, a satisfactory result is obtained for the industry and the producer (FRAGA, et al., 2015). TAVÁRES \& SANTOS (2016), pointed out that an excellent ally for the sector's economy is genetic selection, which leads to the standardization of broiler chickens in terms of body weight, carcass yield and feed conversion, reaching the possibility of bird slaughter in the shortest time. Genetic selection, along with rapid growth; however, does not always achieve such responses, and the incidence of abnormal physiological behavior begins to appear more frequently and is extremely visible and significant in chicken breasts.

A significant occurrence concerning breast anomalies of broilers is deep pectoral myopathy (or green muscle disease), commercially known as "breast fillets with degeneration, necrosis and atrophy", which occurs, according to ZIMERMANN (2008), when oxygenation ceases in the smaller pectoral muscles (Pectoralis minor). Some authors also report that it can be caused when the blood circulation stops by intense muscular exercise, like the voluntary movement of the wings. According to ABASHT et al., (2016) and MUDALAL et al., (2014), this myopathy has been reported in several countries around the world, including the United States, Finland, Italy and Brazil. There is an enormous economic burden imposed on the poultry industry because of this anomaly, since the consequences of muscular abnormalities, such as White Striping (WS) and Wooden Breast (WB), cause a significant reduction in the quality of chicken meat. The fillets provided with WB are often substandard processing units, causing significant economic losses for the industry. In the raw state, breast fillets with the WB condition are characterized by abnormal tissue hardness, total muscle stiffness and a protruding shape at the skull end with a ridge-like protrusion at the caudal end of the fillet (BOWKER et al., 2019; PETRACCI et al., 2019).

Therefore, during the deboning process, this muscle is condemned. Still, when there is whole chicken production, it is not possible to identify it, because according to Ordinance No. 210, dated November 10, 1998, the suprahyoid muscle is exposed when the carcass is the result of a more detailed evaluation by the Department of Final Inspection (DIF) or in the boning room. However, PEREIRA et al., (2005), made a study about myopathy and found to be a technopathy, that is to say, disease caused by changes in the technology is possible to adapt pre-slaughter problems to reduce the damages caused, but that can be consumed since it is not an issue of food safety, but a product quality problem. KIJOWSKI \& KONSTANCZAK (2009), further emphasized that the green color is probably the result of a transformation of myoglobin under anaerobic conditions and not inflammation.

In addition to Deep Pectoral Myopathy, other breast and breast fillets anomalies have caused damage to abattoir. SIHVO et al., (2013), reported that there was an increase in chicken breast with abnormalities in Finland, characterizing the Pectoralis major, pale and hard outer areas with white strips, leading to consumer rejection and; consequently, economic losses in the industry. The authors also mention that they did not find any relation to such anomalies with any antemortem symptom. There is also an ongoing research on an occurrence of a yellowish color accompanied by inflammatory processes and necrosis, besides the hardness (WB) on chicken breast. The two anomalies have similar histological characteristics. Knowledge is scarce about the implication in the quality of the products, as well as the forming mechanisms (ZOTTE et al., 2017). 
BAILEY et al., (2015), also emphasized that deep pectoral myopathy occurs when there is ischemic necrosis of the breast muscle, as a result of the wing-lifting effort, where the muscle is unable to expand. White Stripes of the breast are related to adipose tissue through histological and chemical analyses. The WB is related to the connective tissue characterized by the hardness of the muscle. When an animal dies, a failure in the blood circulation occurs, due to bleeding and; consequently, interruption in the supply of oxygen and nutrients. The metabolism uses the oxygen bound to myoglobin to continue the aerobic process. When this oxygen ceases, the main metabolic pathway for ATP generation becomes the glycogen reservoir. Thus, already in anaerobiosis, there is a production of lactic acid and reduction of the ATP concentration until it disappears. Consequently, the actin-myosin interactions begin, forcing the muscle to enter a phase of continuous contraction until it comes to an irreversible conversion known as rigor mortis. Thus, glycogen levels begin to decrease, while lactic acid forms in anaerobic metabolism and, when it cannot be eliminated, it accumulates in the muscle fiber serving as an indicator of the rate of post-mortem glycolysis and directly reflects its reduction after 24 hours of slaughter. Finally, there is a proteolytic breakdown of the muscular structure, which can last up to two weeks, with an increase in the flexibility and tenderness of the meat, this last stage is known as, post rigor mortis (CARVALHO et al., 2018).

According to KRALIK et al., (2014), animals that stayed long and underwent stress had their glycogen reserves diminished, allowing the $\mathrm{pH}$ to remain stable, ending at around 6.0. At this point, the flesh of these animals show an anomaly known as Dark, Firm and Dry (DFD), presenting a dark color, firm texture and high water holding capacity. Another anomaly caused by stress is known as Pale, Soft and Exudative (PSE): light color, soft texture and much exudation, in which case the meat reaches its final $\mathrm{pH}$ in a short time and have a denaturation of proteins, consequently.

In addition to these factors, CARVALHO et al., (2018), affirmed that lipid oxidation is one of the leading non-microbial causes affecting meat quality. It can be initiated by external or internal factors and affect nutritional and functional properties, such as water holding capacity. According to OLIVO $\&$ SHIMOKOMAKI (2002), when the animal is sacrificed, autocatalytic peroxidation begins, being influenced by factors such as $\mathrm{pH}$, temperature and deboning, which provoke protein denaturation and iron release, resulting in the generation of free radicals and the propagation of reactions oxidative. KUTTAPPAN et al., (2013), adds that missing the lack of sufficient blood supply can result in the accumulation of metabolic waste products leading to oxidative stress and tissue damage. According to PETRACCI \& CAVANI (2012), it is known that dietary tocopherol levels may delay initiation of oxidation and loss of meat quality, but there are few studies on how the nutrients in a diet affect meat quality.

It is known that WS affected meats tend to have higher lipid content (ZAMBONELLI, et al., 2016; BALDI, et al., 2017, VELLEMAN, 2019), these authors suggested that the high rates of lipid material reported in this type of material is directly associated with the type of metabolic alteration. Since the inflammatory process leads to the production of adipose tissue and collagen in the affected region; consequently, a higher rate of oxidation of this material, leading to losses in nutritional quality and sensory. Moreover, the development of reheat aroma in poultry meat is notorious, and since there is a higher probability of oxidation, this undesirable aroma can be pronounced, further affecting the sensorial characteristics of thermally treated products. The organization and nature of proteins in skeletal muscle have essential effects on how they are reversed metabolically. Skeletal muscle presents three classes of proteins according to their solubility; the main class is the myofibrillar, because the myofibrillar proteins are assembled in myofibrillar structures in the striated muscle, which pose a unique challenge to protein turnover. Based on recent advances in understanding this protein system, there are indications that myofibrillar proteins are first hydrolyzed before they can be degraded and reused. It is not clear how this dissociation occurs; it may involve the release of a group of easily hydrolyzable myofilaments or may involve an exchange of myofibrillar proteins in the cytoplasm of the cell, or both mechanisms may occur at the same time (GOLL et al., 2008).

These same authors affirmed that calpastatin appears to be the variable component of the calpain system, and the activity of calpastatin in skeletal muscle is highly related to the rate of muscle protein turnover and post-mortem turnover rate. The current paradigm is that the high activity of calpastatin may: a) decrease the turnover rate of muscle protein; and therefore, is associated with an increase in muscle growth rate and b) decrease calpain activity in the post-mortem muscle and; therefore, is associated with a lower softening rate. It was initially proposed that the calpain system would be responsible for initiating the turnover of myofibrillar proteins and would; therefore, only affect

Ciência Rural, v.50, n.11, 2020. 
the rate of muscle protein degradation (GOLL et al., 2008). Studies by SHALINI et al., 2015; KWAK, et al., 1993; BARNOY et al., 1997, showed that calpain activity is required for myoblast fusion and cell proliferation. Thus, the calpain system can also affect the number of skeletal muscle cells (fibers) in animals by altering the proliferation rate of myoblasts and modulating the fusion of these. A review published in 2000 by SCHREURS contains relevant information on post-mortem changes in poultry meat. This author commented on those alterations in muscular development, giving emphasis to dystrophies and stating that there is a considerable increase in the protein degradation and; consequently, an increase in the activity of the proteases, while the activation of the calpain system is vigorously active.

LEE et al., (2008), indicated that for chicken breast, the action of proteases seems to differ when compared to mammals, $\mu$-calpain disappears within 24 hours after slaughter and m-calpain are still active for several days. In chicken breast, the rapid intervention of calcium-dependent proteases; and consequently, the early onset of $30 \mathrm{KDa}$ peptides may explain the quick softening in poultry. These peptides are observed between 6 and 12 hours post-mortem in mammals and are results of the partial hydrolysis of troponin $\mathrm{T}$ by the action of the calpains. In a study published by BLANCHARD \& MANTLE (1996), there is a breakdown of proteolytic groups in poultry meat as compared to sheep, pigs and rabbits.

In this study, there was a higher concentration of calpains in poultry when compared to the others, and there is a difference for cathepsins as well as multicatalytic proteinases. This leads again to the research of LEE et al., (2008), which mentioned that there are groups of proteases that are more active in poultry meats, but not specify which group of proteases are these, but makes clear that it is not the calpain system. In addition to the information quoted above on quality parameters for chicken meat, a focus on other lines of research that may provide differentiated responses is necessary because it leads to the answers that industries are looking after. Therefore, research on protein turnover in broilers has been carried out for a considerable time; although, much is still unknown. However, protein turnover in laying matrices indicated differences between age, sexual maturity, posture period, and feeding system. Genetic research with genes related to protein degradation (IGF-1, ampk, antrogine-1, MURF1, and Cathepsin B) is being developed, but its expression changes due to changes in protein turnover. These genes have already been sequenced for broilers (DUPONT et al., 1998; BIGOT et al., 2003; TOSCA et al., 2006).

The article published in 2017 by VIGNALE, et al., makes exciting comments on the matter; some of which can be summarized as: a) Protein synthesis rates are not different for Normal meats or WS, but the protein degradation rates diverge between them. Also, the increased expression of the MuRF1 gene and Antrogine 1 is responsible for the higher rates of protein degradation. Despite these sequencing, there is still unknow the protein changes in poultry. Although, there is scarce information regarding broiler chickens, the industry faces two situations that need to be elucidated, which are the appearance of WS in poultry and the positive effect of breast meat yield following the supplementation of 25OH-D3. This supplementation has been shown to be useful for commercial use because it improves poultry growth performance. It is known that the addition of vitamin D3 improves the weight gain and feed efficiency of broilers, as well as the improvement in the development of the pectoral muscle (YARGER, et al., 1995). However, the underlying molecular mechanisms for this improvement are still unknown.

Besides the possibilities involving protein turnover, calpains system, and how this can influence the muscular development, there are still other hypotheses that are being raised to define the process of meat formation with WS anomaly better. One of them is associated with mitochondrial content, indicating the possibility of a low concentration of mitochondria in these muscles (REVERTER et al., 2017). This could explain the need for cicatrization processes of these muscles, which are characterized by the striation of the musculature, indicating the need for connective tissue deposition.

There is also, through metabolomic studies, the observation of the increase in the concentrations of citrate, malate and fumarate, products from the Krebs Cycle, which in excess can cause changes in the metabolic processes, leading to mitochondrial damage. Another strong point associated with mitochondrial activity - which is commented by BOERBOOM et al., (2018); PAMPOUILLE et al., (2018); ABASHT et al., (2016) - is the increase in the concentration of medium and long-chain fatty acids and a decrease in acylcarnitine esters involved in the transport of long-chain fatty acids into the mitochondria. That suggested that there is a pattern alteration in the $\beta$-oxidation (BOERBOOM et al., 2018; MUTRYN et al., 2015). Publications by ABASHT et al., (2016); MUTRYN et al., (2015); KRAMEROVA, et al., (2009) and XIAOFANG et 
al., (2018), indicated that in the process of oxidative stress, which may originate from heat stress or another mechanism that leads to WS-like alterations, a malformation of the mitochondria occurs. This malformation leads to an internal membrane rupture, as well as to a significant decrease in the amount of it that is available to the tissue. Consequently, these organelles enter into oxidative stress resulting in an alteration in the skeletal musculature.

In addition to the quality and quantity of the mitochondria, KRAMEROVA et al., (2009) and ZHANG et al., (2011), comment that Calpain 3 is one of the proteases that regulate myogeny and that in traits affected in dystrophic or prominent proteolytic processes. Studies by KRAMEROVA et al., (2009), have shown Calpain 3 is necessary for the control myoblast fusion and their transition to the terminal stages of muscle differentiation and they agree could be possible anchored to the sarcomere through its interaction with a large myofibrillar protein titin, which serves as a scaffold for sarcomeric proteins. Localization of Calpain 3 near myofibrillar proteins may allow it to play a role in their turnover. Conversely, ZHANG, et al., (2011), suggested that this Calpain is a regular activity of Calpain 1 and 2 by the action of calpastatin. The same authors indicated that Calpain 3 can increase the hydrolysis rate of titin.

\section{CONCLUSION}

In the face of the various studies conducted by researchers from around the world, we concluded be this theme is central to a relevant setting for the processing of poultry meat industries, since it involves considerable financial matters. For the Brazilian market, there are estimated values of $\$$ $70,632.00$ thousand / day for convictions in the poultry sector, mostly associated with myopathies. So, it is indispensable both the use of scientific research and development for the reduction of management losses and industrialization as well as the financial loss by the lack of them. Aspects such as animal welfare, genetic improvement and proper industrialization have a strong positive impact on the quality of the product to be offered to the final consumer and currently the central problems of this study such as white striping, and wooden breast created barriers for this quality to be achieved. It is understood that each market has its cultural particularities and every study must be based on these characteristics, but what we cannot ignore is the nutritional quality of processed products and the constant search for new alternatives and studies for an understanding of how anomalies influence this quality, being this an essential condition for future improvements in this sector and reduction of the considerable losses currently observed by the sector.

\section{ACKNOWLEDGMENTS}

The authors would like to thank the Coordenação de Aperfeiçoamento de Pessoal de Nível Superior (CAPES), and Conselho Nacional de Pesquisa $(\mathrm{CNPq})$ for the possibility of developing this research. Especially the author MRP thanks for the granting of DT2 CNPq process number 314636 / 2018-8. The authors are grateful to the Multiuser Laboratory of Federal University of Technology - Paraná -Campus Londrina - for the performed analyzes.

\section{DECLARATION OF CONFLICT OF INTERESTS}

The authors declare no conflict of interest. The founding sponsors had no role in the design of the study; in the collection, analyses, or interpretation of data; in the writing of the manuscript, and in the decision to publish the results.

\section{AUTHORS' CONTRIBUTIONS}

All authors contributed equally for the conception and writing of the manuscript. All authors critically revised the manuscript and approved of the final version.

\section{REFERENCES}

ABPA - ASSOCIAÇÃO BRASILEIRA DE PROTEÍNA ANIMAL. 2019. Relatório anual 2018. Available from: $<$ http://abpa-br.com.br/storage/files/relatorio-anual-2018.pdf $>$. Accessed: Jun. 30, 2019.

ABASHT, B., et al. Oxidative stress and metabolic perturbations in wooden breast disorder in chickens. PLoS ONE, 11(4). 2016. Available from: <https://doi.org/10.1371/journal.pone.0153750>. Accessed: Nov. 12, 2019.

BAILEY, R. et al. The genetic basis of pectoralis major myopathies in modern broiler chicken lines. Poultry Science, 94:2870-2879. 2015. Available from: <https://www.sciencedirect.com/science/article/pii/ S0032579119321182?via\%3Dihub>. Accessed: Nov. 12, 2019.

BALDI, G. et al. Implications of white striping and spaghetti meat abnormalities on meat quality and histological features in broilers. Animal, 12(1), 164-173. 2017. Available from: <https://doi. org/10.1017/S1751731117001069>. Accessed: Jan. 12, 2019.

BARNOY, S. et al. Calpain and calpastatin in myoblast differentiation and fusion effects of inhibitors. Biochim. Biophys. Acta, 1358: 181-188. 1997. Available from: <https://doi. org/10.1016/S0167-4889(97)00068-2>. Accessed: Jan. 12, 2019.

BLANCHARD, P. J.; MANTLE, D. Comparison of proteolytic enzyme levels in chicken, pig, lamb and rabbit muscle at point of slaughter: role in meat tenderisation post mortem. Journal of the Science of Food and Agriculture, 71(1), 83-91. 1996. Available from: $<$ https://doi.org/10.1002/(sici)1097-0010(199605)71:1<83::aidjsfa552>3.3.co;2-6>. Accessed: Jul. 24, 2019. 
BOERBOOM, G. et al. Unraveling the cause of white striping in broilers using metabolomics, Poultry Science, 97(11), 39773986. 2018. Available from: <https://doi.org/10.3382/ps/pey266>. Accessed: Aug. 02, 2019.

BIGOT, K. et al. Refeeding andinsulin regulate S6K1 activity in chicken skeletal muscles. The Journal of nutrition. . 133: 369-373. 2003. Available from: <https://academic.oup.com/ jn/article/133/2/369/4687876>. Accessed: Dec. 10, 2019. doi: $10.1093 / \mathrm{jn} / 133.2 .369$

BOWKER, B. et al. Relationships between attributes of woody breast and white striping myopathies in commercially processed nroiler breast meat, The Journal of Applied Poultry Research, Volume 28, Issue 2, June 2019, Pages 490-496. 2019. Available from: <https://doi.org/10.3382/japr/pfz007>. Accessed: Nov. 06, 2019.

CARVALHO, R. H. et al. Further evidence for the existence of broiler chicken PFN (pale, firm, non-exudative) and PSE (pale, soft, exudative) meat in brazilian commercial flocks. Food Science and Technology, 38(4), 704-710. Epub April 16, 2018. Available from: $<$ https://dx.doi.org/10.1590/fst.15617>. Accessed: Jul. 14, 2018.

DUPONT, J. et al. Nutritional state regulates insulin receptor and IRS1 phosphorylation and expression in chicken. $\mathbf{J}$ Physiol Endocrinol Metab, 274:E309-E316. 1998. Available from: <https://journals. physiology.org/doi/full/10.1152/ajpendo.1998.274.2.E309>. Accessed: Jul. 14, 2018.

FRAGA, S. T. et al. Estudo anátomo-patológico do músculo pectoralis major de frangos de corte acometidos com Wooden Breast (WB). $\mathbf{4 2}^{\circ}$ Congresso Bras. de Medicina Veterinária e $1^{\circ}$ Congresso Sul-Brasileiro da ANCLIVEPA - Curitiba. 2015.

GOLL, D. E. et al. Myofibrillar protein turnover: The proteasome and the calpains, Journal of Animal Science, Volume 86, Issue suppl_14, April Pages E19-E35. 2008. Available from: <https:// doi.org/10.2527/jas.2007-0395>. Accessed: May, 02. 2017.

KIJOWSKI, J.; KONSTANCZA, M. Deep pectoral myopathy in broiler chickens. Bulletin of the Veterinary Institute in Pulawy, 53(3), 487-491. 2009. Available from: <https://doi.org/10.12681/ jhvms.15088>. Accessed: Dec. 10, 2019.

KRALIK, G. et al. Quality indicators of broiler breast meat in relation to colour, Animal Science Papers and Reports, 32, 173178, 2014. Available from: <http://archiwum.ighz.edu.pl/files/ objects/7490/66/strona173-178.pdf $>$. Accessed: Dec. 10, 2019.

KRAMEROVA, I. A. et al. Mitochondrial abnormalities, energy deficit and oxidative stress are features of calpain 3 deficiency in skeletal muscle. Human Molecular Genetics, 18(17), 3194-3205. 2009. Available from: <https://doi.org/10.1093/hmg/ddp257>. Accessed: Aug. 01, 2018.

KUTTAPPAN, V. A. et al. Pathological changes associated with white striping in broiler breast muscles. Poultry Science, 92(2), 331-338, 2013. Available from: <https://doi.org/10.3382/ps.201202646>. Accessed: Aug. 01, 2018.

KWAK, K. B. et al. Cell-penetrating inhibitors of calpain block both membrane fusion and filamin cleavage in chick embryonic myoblasts. FEBS Letters, 323:4;323(1-2):151-4. 1993. Available from: <https://www.sciencedirect.com/science/
article/pii/001457939381468F>. Accessed: Sep. 03, 2018. doi: 10.1016/0014-5793(93)81468-f.

LEE, H. L. et al. Role of calpains in postmortem proteolysis in chicken muscle. Poultry Science, 87(10), 2126-2132. 2008. Available from: <https://doi.org/10.3382/ps.2007-00296>. Accessed: Aug. 15. 2018.

MUDALAL, S. et al. Quantity and functionality of protein fractions in chicken breast fillets affected by white striping. Poultry Science, 93(8), 2108-2116. 2014. Available from: <https://doi.org/10.3382/ ps.2014-03911>. Accessed: Feb. 02, 2018.

MUTRYN, M. F. et al. Characterization of a novel chicken muscle disorder through differential gene expression and pathway analysis using RNA-sequencing. BMC Genomics, 16(1). 2015. Available from: <https://doi.org/10.1186/s12864-015-1623-0>. Accessed: Sep. 07, 2019.

OLIVO, R.; SHIMOKOMAKI, M. Carnes: No Caminho da Pesquisa. 2 edição. Cocal do Sul: IMPRINT. 2002.

OECD/FAO. 2018. OECD-FAO Agricultural Outlook 2018-2027, OECD Publishing, Paris/Food and Agriculture Organization of the United Nations, Rome. Available from: <https://doi. org/10.1787/agr_outlook-2018-en>. Accessed: Feb. 19, 2019.

PAMPOUILLE, E. et al. Mapping QTL for white striping in relation to breast muscle yield and meat quality traits in broiler chickens. BMC Genomics, 19(1). 2018. Available from: $<$ https:// doi.org/10.1186/s12864-018-4598-9>. Accessed: Feb. 14, 2019.

PEREIRA, R. A. et al. Miopatia peitoral profunda em frangos de corte. Veterinária em foco, v.3, n.1, p.11-15, 2005. Available from: $<$ https://www.ulbra.br/upload/f1f234f16db1 fae25d44d7929d070aa8. pdf\#page=11>. Accessed: Dec. 10, 2019.

PETRACCI, M.; CAVANI, C. Muscle growth and poultry meat quality issues. Nutrients. (review), v.4, p.1-12. 2012. Available from: $<$ https://doi.org/10.3390/nu4010001>. Accessed: Jan. 05, 2018.

PETRACCI, M. et al. Wooden breast, white striping, and spaghetti meat: causes, consequences and consumer perception of emerging broiler meat abnormalities. Comprehensives Reviews in Food Science and Food Safety. 00.1-19. 2019. Available from: $<$ https:// doi.org/10.1111/1541-4337.12431>. Accessed: Sep. 15, 2019.

REVERTER, A. et al. Chicken muscle mitochondrial content appears coordinately regulated and is associated with performance phenotypes. Biology Open, 6(1), 50-58. 2017. Available from: $<$ https://doi.org/10.1242/bio.022772>. Accessed: Sep. 27, 2018.

SIHVO, H. K. et al. Myodegeneration with fibrosis and regeneration in the pectoralis major muscle of broilers. Veterinary Pathology, 51(3), 619-623. 2013. Available from: <https://doi. org/10.1177/0300985813497488>. Accessed: Sep. 15, 2019.

SCHREURS, F. J. G. Post-mortem changes in chicken muscle. World's Poultry Science Journal, 56(4), 319-346. 2000. Available from: <https://doi.org/10.1079/wps20000023>. Accessed: Oct. 02, 2018.

SHALINI, S. et al. Old, new and emerging functions of caspases. Cell Death and Differentiation. Apr. 4. 2015. Nature Publishing Group. Available from: <https://doi.org/10.1038/cdd.2014.216>. Accessed: Oct. 02, 2018. 
TAVÁRES, M. A.; SANTOS, F. S. Impact of genetics and breeding on broiler production performance: a look into the past, present, and future of the industry, Animal Frontiers, Volume 6, Issue 4, October 2016, Pages 37-41. Available from: <https://doi. org/10.2527/af.2016-0042>. Accessed: Dec. 11, 2019.

TOSCA, L. et al. AMP-activated protein kinase activation modulates progesterone secretion in granulosa cells from hen preovulatory follicles. Journal of Endocrinology 190, 85-97. 2006. Available from: $<$ https://joe.bioscientifica.com/view/journals/joe/190/1/1900085. xml>. Accessed: Oct. 13, 2018. doi: 10.1677/joe.1.06828.

VIGNALE, K. et al. Effect of white striping myopathy on breast muscle (Pectoralis major) protein turnover and gene expression in broilers. Poultry Science, 96(4), 886-893. 2017. Available from: $<$ https://doi.org/10.3382/ps/pew315>. Accessed: Nov. 15, 2017.

YARGER, J. G. et al. Comparison of dietary 25-hydroxycholecalciferol and cholecalciferol in broiler chickens. Poultry Science. 74:1159-67. 1995. Available from: $<$ https://www. sciencedirect.com/science/article/pii/S003257911945476X $>$. Accessed: Mar. 03, 2018. doi: 10.3382/ps.0741159.

XIAOFANG, H. E. et al. Chronic heat stress damages small intestinal epithelium cells associated with the adenosine 5 '-monophosphate-activated protein kinase pathway in broilers. Journal of Agricultural and Food Chemistry, 66(28),7301-
7309. 2018. Available from: <https://pubs.acs.org/doi/10.1021/ acs.jafc.8b02145>. Accessed: Jan. 15, 2019. doi: 10.1021/acs. jafc. $8 \mathrm{~b} 02145$.

ZAMBONELLI, P.; M. et al. Detection of differentially expressed genes in broiler pectoralis major muscle affected by white striping - wooden breast myopathies. Poultry Science, 95(12), 27712785. 2016. Available from: $<$ https://doi.org/10.3382/ps/pew268>. Accessed: Jan. 12, 2018.

ZHANG, J. X. et al. Association of polymorphisms in the calpain I gene with meat quality traits in Yanbian yellow cattle of China. Asian-Aust Journal of Animal Science. 24:9- 16. 2011. Available from: <https://www.ajas.info/journal/view.php?number=22430>. Accessed: Dec. 11, 2019. doi: 10.5713/ajas.2011.90407.

ZIMERMANN, F. C. Miopatia dorsal cranial em frangos de corte. 2008. 83f. Dissertação (Mestrado em Ciências Veterinárias) Faculdade de Veterinária, Universidade do Rio Grande do Sul, Porto Alegre. Available from: <http://hdl.handle.net/10183/60576>. Accessed: Sep. 25, 2018.

ZOTTE, A. D. et al. Effect of "wooden breast" appearance on poultry meat quality, histological thaits and lesions characterization. Czech Journal of Animal Science, 62(2), 51-57. 2017. Available from: <https://doi.org/10.17221/54/2016-CJAS>. Accessed: Dec. 10, 2019. 